\title{
Principle of reasonable and legitimate expectations in international law as a premise for investments in the energy sector
}

\author{
Michał Krzykowski ${ }^{1}$ (D) Michał Mariański ${ }^{2}$ (D) Jakub Zięty ${ }^{1}$ (i)
}

Accepted: 7 February 2020 / Published online: 10 March 2020

(c) The Author(s) 2020

\begin{abstract}
A stable and predictable legal environment is one of the basic factors considered in the investment process. It is of particular importance in the energy sector with its characteristically long-term investments which require substantial financial outlays. It has to be underlined that the nature of energy industry is rapidly changing both from the overall shape of the investment and regulatory models. One can observe that the model of the energy market that used to be based on state monopoly evolved into private or half private structure. However, of the particular importance is the fact that together with liberalisation and privatisation of the market the state becomes an active regulator of the market. It is especially noticeable in renewable energy sector in which governments by anticipating and incentivizing are creating conditions for new investments. Simultaneously, one cannot ignore that the state active regulatory policy may also bring a risk that support for certain investments will last as long as it is necessary to achieve its goals such as environmental protection, the need to strengthen awareness or equalise support costs. Therefore, abrupt change in the legal framework may affect the previously accepted financial set-up of the investment. In extreme cases, the change may make the investment unprofitable and thereby cause damage to the investor. This raises the question as to what legal remedies are available to foreign investors in the event of an unexpected and unjustified revision of the legal environment by the host state, provided that said revision causes damage to the investor. The authors assume the following thesis: the investor's interests are protected under the principle of reasonable and legitimate expectations established in the framework of international law. The practical aspect of the hypothesis is also related to the question of the legal force of the arguments contained in the cases that were analysed and given as an example in the paper. As the paper analyses the principle of reasonable and legitimate expectations in the framework of international law through the prism of the investments in the energy sector, it is reasonable to verify the hypothesis regarding the effectiveness of the said principle as a legal basis for bringing claims by the investor. By analysing the doctrine itself and the related legislation and judgements, the authors shall attempt to determine when, and under what conditions, it is possible to apply the principle of reasonable and legitimate expectations in order to minimise the regulatory risk of an investment.
\end{abstract}

Extended author information available on the last page of the article 
Keywords Energy sector · Legitimate expectations - Investments - Stable and predictable legal environment $\cdot$ Change in the legal framework

\section{Introduction}

As a result of globalisation (Yannaca-Small 2008; Reinisch 2008), the share of foreign capital in the energy sector investments continues to grow. ${ }^{1}$ This tendency is reinforced by the image of such projects as a relatively safe and stable option for investing financial surpluses, despite the changing nature of energy sector. After all, modern economies could hardly function without energy, regardless of its form. Potential investors are also encouraged by a range of support programmes, promoting i.a. renewable energy sources or highefficiency cogeneration, which often ensure above-average returns on the invested capital (Przybojewska 2017; Jeżewski 2011). The authors would like to underline that the analysis is focused on the precise contours of the energy sector and its distinct nature, especially in the field of the general concept of state security. It is even more important in relation to long-term perspective of the investments, sensitivity and vulnerability to changes, and relatively high initial capital assets, that have very often international roots.

However, this situation raises the question as to what legal remedies are available to foreign investors in the event of an unexpected and unjustified revision of the legal environment by the host state, provided that said revision causes damage to the investor. For the purposes of further deliberations, let us assume the following thesis: the investor's interests are protected under the principle of reasonable and legitimate expectations established in the framework of international law. ${ }^{2}$ Exploring such a thesis seems justified as no relevant research has been focused explicitly on the energy sector, even though the concept of reasonable and legitimate expectations has been discussed in many studies (Rahdert 1986, 1998; Henderson 1990; Reinisch and Knahr 2008; Feinman 2014; Walter 2008; Brown 2008; Tudor 2008; Boute 2012; Schreuer and Kriebaum 2010) and in arbitration proceedings. ${ }^{3}$

In line with the proposed thesis, the authors have focused on the analysis and assessment of the principle of reasonable and legitimate expectations in the framework of international law through the prism of investments in the energy sector. To fulfil this aim, it is reasonable to verify the hypothesis regarding the effectiveness of this principle as a legal basis for bringing claims by the investor and to consider its connection to other principles arising from the standard of fair and equitable treatment, such as the principle of economic

\footnotetext{
1 Pursuant to Art. 1.6 of the Energy Charter Treaty, "investment" is understood as "every kind of asset, owned or controlled directly or indirectly by an Investor". However, in accordance with the definition, "investment" refers to all investments related to the operations in the energy sector, i.e. all operations related to exploration, extraction, refining, production, storage, land transport, transmission, distribution, trade, marketing or sale of energy materials and products. In the light of the definition, energy investments include both projects based on renewable energy sources and others, e.g. increasing the energy efficiency in the area of generation, transmission, distribution and trade in the energy sector.

2 The difference between expressions "unexpected" and "unjustified" is not very clear. They have been used very often by the tribunals as a synonym without taking into account the smooth difference in their meaning. In the authors' opinion, the expression "unexpected" is rather related to the unpredictable fact, while "unjustified" pays attention to the incompatibility with the legal framework.

3 As demonstrated below.
} 
equilibrium (Varian 1992) ${ }^{4}$ or the requirement to secure a stable legal framework. Another aspect of the hypothesis is the answer to the question of the legal force of the arguments contained in the analysed cases in receiving compensation for loss or decrease in the investment's profitability (understood as the damage to investors).

The structure of the publication has been planned to best present its aim and hypothesis. The paper comprises an introduction, an explanation of the term "reasonable and legitimate expectations", an analysis of selected tribunal rulings and conclusions. The publication is focused on the judgements of arbitration tribunals relevant to the energy sector and invoking the principle of reasonable and legitimate expectations as a basis for settling the dispute. Since the selection of cases (encompassing most of the published judgements on energy relevant in the context of the principle of reasonable and legitimate expectations) is aimed at exploring crucial issues affecting the investor's situation in the energy sector. Therefore, the discussed judgements deal with matters such as liberalisation of the market, change in the market model, long-term contracts or support system for renewable energy sources.

\section{The notion of reasonable and legitimate expectations in the framework of international law}

As indicated by C. Brown, the principle of reasonable and legitimate expectations (Camby 2006; Merzouk 2003; Michel 2009; Potestà 2013; Turpin 2003) ${ }^{5}$ —-sometimes referred to as the principle of basic expectations-is concerned with the right of every person to legal protection in the event of damage caused by the actions taken by state authorities and arising from an unexpected change to their earlier standpoint (Brown 2008). In the framework of international law, said principle is derived from the standard of fair and equitable treatment. ${ }^{6}$ The starting point for the assessment of any state's compliance with this principle is the requirement to ensure that international investments are treated in a manner which does not frustrate basic expectations that the foreign entity relies upon at the moment of

\footnotetext{
${ }^{4}$ Economic equilibrium is a state where economic forces such as supply and demand are balanced and in the absence of external influences the (equilibrium) values of economic variables will not change.

5 Let us observe at this point that the discussed doctrine is recognised in the EU law as well. In the case Branco v. Commission, the court of first instance declared as follows: "Three conditions must be satisfied in order to claim entitlement to the protection of legitimate expectations. First, precise, unconditional and consistent assurances originating from authorised and reliable sources must have been given to the person concerned by the Community authorities. Second, those assurances must be such as to give rise to a legitimate expectation on the part of the person to whom they are addressed. Third, the assurances given must comply with the applicable rules", Judgement of GSUE T-347/03 in the case Branco v. Commission, point 102, European Court Reports 2005 II-02555. See also: Judgement of TSUE C-331/88 in the case MAFF, European Court Reports 1990 I-04023, and Judgement of TSUE C-345/06 in the case Heinrich, European Court Reports 2009 I-01659. Besides, the principle is applied also in the legislations of various nations. For more information see: Decision of Conseil Constitutionnel of 21 January 1994, No. 93-335 DC; the Decision of the Constitutional Council of 29 December 2005, No. 2005-530 DC.; Judgement of the Court of Cassation, Second Civil Division, 10 July 2008, no. 07-12.072, Bull. no. 177; Judgement of the Court of Cassation, Criminal Division, 13 June 2001, no. 00-85.289, Bull. no. 144; Judgement of the Court of Cassation, Commercial Division, of 22 October 2002, no. 01-01.960, Bull. no. 147; Judgement of the Court of Cassation, First Civil Division., of 11 June 2009, no. 07-14.932.

6 See: Biwater Gauff Ltd. v. Tanzania (24 July 2008), Arb/05/22 ICSID, point 602; see also: National Gird P.L.C. v. Argentina (3 November 2008), UNCITRAL, point 168.
} 
the investment. ${ }^{7}$ Thus, in order to establish whether or not the principle of reasonable and legitimate expectations has been violated, it is necessary to consider three basic factors: the state's promise which renders the state liable for damages, reasonable and legitimate expectations based on objective assessment, and a positive decision if both preceding conditions have been satisfied (Jeżewski 2011). In order to establish whether the principle has been violated, the original state of affairs as at the moment of the investment decision needs to be compared with the situation as at the moment of the introduction of changes made by the state and affecting the situation of the investor. If an analysis of the facts reveals a material violation of the original obligations assumed by the state, one which cannot be justified by any extraordinary circumstances, the state shall be held liable for the losses incurred by the investor.

The judgements of arbitration tribunals indicate that the notion of reasonable and legitimate expectations is relevant when the actions of a contracting party lead the investor to develop reasonable and legitimate expectations regarding the behaviour of said party. ${ }^{8}$ The principle is contemplated in a more detailed manner in the doctrine. At this point, let us invoke the standpoint of J. M. Feinman who argues that the expectations themselves should have a bearing on the circumstances of making the promises, entering into the agreements or assuming the obligations in question. Sometimes, the expectations may be created by representations or actions of the other party. Thus, in each particular case, the essence of the expectations must be determined by a judicial authority (Feinman 2014; Burton and Andersen 1995). Such a determination should be based on objective criteria, taking into account the context of all actions. The context may involve specific legal regulations, official strategies adopted by the state or the provisions of the concession granted.

Meanwhile, A.L Corbin contends that reasonableness, characteristic of the expectations, is a category "no more absolute in character than is justice or morality. Like them, it is an expression of the customs and mores of men-the customs and mores that are themselves complex, variable with time and place, inconsistent and contradictory" (Feinman 2014). The second feature of the expectations - their legitimacy - should be considered in a similar vein. As emphasised by $\mathrm{Ch}$. Schreuer and U. Kriebaum: "the purpose of protecting legitimate expectations is to enable the foreign investor to make rational business decisions in reliance on the representations made by the host state" (Schreuer and Kriebaum 2010). This category is also closely related to the requirements of stability and predictability.

The principle of reasonable and legitimate expectations as understood above may be found in the arbitration tribunal decisions selected by the authors.

In the case Saluka v. the Czech Republic, ${ }^{9}$ the Arbitral Tribunal emphasised that "the scope of the Treaty's protection of foreign investment against unfair and inequitable treatment cannot exclusively be determined by foreign investors' subjective motivations and considerations. Their expectations, in order for them to be protected, must rise to the level

\footnotetext{
7 In the award on the dispute between Tecmed and Mexico, it is argued that a foreign investor has the right to expect the host state to act in a logical manner, free from ambiguity and transparent, so that the investor could identify the direction adopted in state policy and legislation relevant to the investment, Tecnicas Medioambienrales Tecmed S.A. v. Mexico (29 May 2003), Arb (AF)/00/2 ICSID, point 154; see also: Enron Corporation Ponderosa Assets L.P. v. Argentina (22 May 2007), Arb/01/3 ICSID, point 262, and Waste Management Inc. v. Mexico (30 April 2004), Arb (AF)/00/3 ICSID, point 98.

8 See: International Thunderbird Gaming Corporation v. Mexico (26 January 2006), UNCITRAL, points $147,148$.

9 Saluka Investments BV v. the Czech Republic (17 March 2006), UNCITRAL.
} 
of legitimacy and reasonableness in light of the circumstances". ${ }^{10}$ Thus, protection under this standard may be claimed only if the investment decision could be affected by objective data, often recorded in official standpoints or documents issued by state authorities, and not the personal belief of the investor that a promise has been made (Jeżewski 2011). ${ }^{11}$ The expectations may vary depending on a range of factors, including the nature of the violation and the circumstances of the case. In the case $L G \& E v$. Argentina, the Arbitral Tribunal described fair expectations as follows: "they are based on the conditions offered by the host State at the time of the investment; they may not be established unilaterally by one of the parties; they must exist and be enforceable by law; in the event of infringement by the host State, a duty to compensate the investor for damages arises except for those caused in the event of a state of necessity". The business and regulatory risk must also be considered. $^{12}$

It cannot be overlooked that the principle of reasonable and legitimate expectations is related to the obligation of securing a stable and predictable legal framework. Arbitral tribunals argue in their decisions that the stability and predictability of the legal framework are an essential element of fair and equitable treatment, much like the discussed principle. ${ }^{13}$ However, it shall be noted that in terms of legal consequences, it is an abstract promise related to the legal and economic system of the host state, as opposed to the principle of reasonable and legitimate expectations where under the promise is made directly to the investor. On the other hand, as observed by M. Jeżewski "(...) from the perspective of the theory of international law, it is irrelevant by whom and in which form the international obligations were assumed on behalf of the state" (Jeżewski 2011). It may be inferred that in terms of liability for the failure to keep a promise, it is of secondary importance whether the investor was given assurances by an administrative authority or by the state which created the legal framework regulating the economic sector in question. Any assurance given by the state refers to a distinctive legal situation for the investment and for the return on the invested assets. Thus, the state guarantees that the legal environment will not be changed in any manner substantively affecting the investment. Needless to say, the relevant time frame is limited by the return on the investment and also the circumstances beyond the control of the host state such as the seizure of its territory by another state. All such assurances of equal consequence made by state authorities-for instance, the promise of granting a concession in energy law - are the acts of enforcing the law and, simultaneously, delivering on the earlier assurance regarding investment conditions.

Essentially, the principle of securing a stable and predictable legal framework rests on the presumption that the investor considers the legal situation in the host state at the moment of making the investment decision and assumes that it will not change drastically to its detriment (Jeżewski 2011). Yet, let us emphasise that the investor needs to be aware that the law in the host state may be adjusted depending on the circumstances and needs. ${ }^{14}$ The right of the state to take appropriate measures in order to prevent, for instance, an

\footnotetext{
10 Ibidem, point 304.

11 See also: Enron Corporation..., point 262.

12 LG\&E ENERGY CORP., LG\&E CAPITAL CORP., LG\&E INTERNATIONAL INC. v. Argentina (3 October 2006), Arb/02/1 ICSID, point 130.

13 Occidental Exploration and Production Company v. Ecuador (2004), London Court of International Arbitration Administered, Case No. UN 3467, point 183.

14 Saluka Investments $B V \ldots$, point 305.
} 
economic or social crisis could hardly be denied. ${ }^{15}$ For this reason, as observed by the Arbitral Tribunal in the case Enron v. Argentina, in principle "stabilization requirement does not mean the freezing of the legal system or the disappearance of the regulatory power of the State". ${ }^{16}$ The rule is valid unless the state and the investor enter into an agreement including a so-called stabilisation clause ${ }^{17}$ which may freeze the legal regulations as at the day of allowing the investment. It needs to be observed that the clause does not limit the right of the host state to adapt its own legal system but ensures that potential alterations will not generate any legal consequences for the investor.

\subsection{Deliberalisation ${ }^{18}$ of the market: the cases: AES v. Hungary and Electrabel $v$. Hungary}

In the light of the above, the cases AES v. Hungary ${ }^{19}$ and Electrabel v. Hungary, ${ }^{20}$ heard by the Arbitral Tribunals at ICSID (under the provisions of the Energy Charter Treaty), are of particular interest.

The former case revolved around long-term contracts for the supply of electric energy (from 1995 and 1996) ${ }^{21}$ to encourage potential investors to privatise and upgrade the existing power plants (Tisza II, Borsod, Tiszapalkonya Power Plants). In the light of the relevant agreements, in exchange for making necessary investments, Hungary agreed to guarantee a certain return on the invested capital (recovery of investment) and cover the operating costs of the project. However, since Hungary failed to perform its obligations arising from the agreement from 10 October 1995 which prolonged the long-term agreements concerning the Tisza II and Borsod AES power plants, AES decided to bring an action before the Arbitral Tribunal.

As a result, on 19 December 2001, both parties concluded a settlement which laid the foundation for signing an annex to the agreement entered into by MVM and AES. Pursuant to the annex, the existing remuneration method was replaced with a new regime, more profitable for the investor and based on prices regulated by the Minister of Economy (Decree No. 55/1996 from 20 December 1996, as amended). The annex was supposed to remain in force as long as Hungary continued the administrative regulation of prices.

However, due to the wariness that the agreements generate inordinate income for the power generation companies, the amount of their "compensation" was reduced. The reasonable return on equity was set at $7.1 \%$ (as opposed to the $8 \%$ rate set forth in the original

\footnotetext{
15 Continental Casualty Company v. Argentina (5 September 2008), Arb/03/9 ICSID, point 258.

16 Enron Corporation Ponderosa Assets L.P. v. Argentina (22 May 2007), Arb/03/09 ICSID, point 261.

17 Parkerings-Compagniet AS v. Lithuania (11 September 2007), Arb/05/8 ICSID, points 332 and 334.

18 Deliberalisation process opposite to liberalisation. In this context, it means increasing the role of state such as introducing energy regulatory price again.

19 AES Summit Generation Ltd. v. Hungary (23 September 2010), Arb/07/22 ICSID.

${ }^{20}$ Electrabel S.A. v. Hungary (30 November 2012), Arb/07/19 ICSID.

21 The main agreement, i.e. the Purchase and Sale Agreement, was entered into on 4 July 1996 between a British company named AES and the Hungarian companies named APV and MVM owned by the Hungarian Treasury. Under the agreement, AES purchased a majority shareholding in the Tisza II, Borsod, Tiszapalkonya power plants. In exchange for the upgrade and maintenance of the power plants, MPV agreed to remunerate AES with availability fees and energy fees (covering the costs necessary to generate electric energy).
} 
agreement). ${ }^{22}$ Simultaneously, Hungary argued that the need for changes resulted from the accession to the European Union and the incompatibility of the existing agreements with the regulations on public aid. In the light of the above, the respondent decided to introduce amendments to the Electricity Law in 2006 and issued new decrees on electric energy prices, thereby lowering the tariffs on electric energy.

In response, AES alleged, among other things, a violation of the provisions of the Energy Charter Treaty on fair and equitable treatment, i.e. reasonable and legitimate expectations (Art. 10.1). ${ }^{23}$

The settlement of the dispute hinged on the time when the legitimate expectations were created. Two time points were considered: either the year 1996, when AES had purchased the shares in the Tisza II power plant, or the year 2001 when, in the wake of the settlement, upgrade and expansion of the installation had started. The claimant argued that in 2001, as opposed to 1996, the respondent had assured that the regulatory price regime would draw to a close by the end of $2003 .{ }^{24}$ At this point, it should be mentioned that, in order to protect the weakest consumers, administratively regulated prices are usually lower than the market rates. Therefore, protection of the market prices, which are usually higher than the regulated rates, is in the interest of the power generation companies. In connection with the matter, the Tribunal decided that legal protection arising from the principle of reasonable and legitimate expectations should be considered as at the moment of making the investment. ${ }^{25}$ Importantly, the Tribunal concluded that both the transfer of stock to the claimant in 1996 and the expenses made to upgrade the power infrastructure in 2001 were, in fact, investments. The enquiry therefore turned to whether the respondent made representations and assurances to the claimant, and whether the respondent acted in a manner contrary to such representations and assurances. ${ }^{26}$ The Tribunal determined that in the case of the agreement from 1996, the claimant made the investment fully aware of the existence of administrative regulation of electric energy prices (taking into account the $8 \%$ return rate). As regards the annex signed in 2001, the claimant knew that administrative pricing would be terminated by the end of 2003 (which indeed happened). However, it cannot be overlooked that the respondent made no individual representations or assurances in connection with the reintroduction of tariffs in future. For this reason, and for the want of evidence supporting the claimant's standpoint, the Tribunal found no basis for the legitimacy of the expectations regarding the absence of administrative pricing after 2003.

A similar attitude was taken in the other case against Hungary. ${ }^{27}$ The findings of fact concerned a Belgian company named Electrabel which, in the years 1995-2001, became a shareholder in Dunamenti. The investment was preceded by the signing of a long-term agreement by the Dunamenti public company (owned by the Hungarian Treasury) and MVM (owned in $99.9 \%$ by the Hungarian Treasury) in $1995 .{ }^{28}$ Under the agreement,

\footnotetext{
${ }^{22}$ AES Summit Generation Ltd. v. Hungary (23 September 2010), Arb/07/22 ICSID, p. 24, points 4.154.18 .

23 Ibidem, p. 26, point 5.1 .

24 Ibidem, p. 58, point 9.3.19.

25 See: Duke Energy Electroquil Partners and Electroquil S.A. v. Republic of Ecuador (18 August 2008) Arb/04/19 ICSID; Técnicas Medioambientales Tecmed, S.A. v. United Mexican States (29 May 2003), Arb/00/2; LG\&E Energy Corp., LG\&E Capital Corp. and LG\&E International Inc. v. Argentine Republic (6 October 2006), Arb/02/1.

26 AES Summit Generation Ltd. v. Hungary, (23 September 2010), Arb/07/22 ICSID, p. 57, point 9.3.17.

27 Electrabel S.A. v. Hungary (30 November 2012), Arb/07/19 ICSID.

28 Electrabel, Part II, p. 2, point 2.5.
} 
Dunamenti agreed to supply energy to MVM as need be and at preferential prices for the duration of 15 years starting from the signing of the agreement. As the agreement guaranteed stable profit, it was aimed to encourage potential investors to participate in the privatisation of the Hungarian energy sector.

However, as the administrative price regulation was reintroduced in the years 2006 and 2007, the company accused Hungary (much like in the previous case) of, among other things, a breach in the fair and equitable treatment of the investors and, specifically, the principle of reasonable and legitimate expectations. In response to the allegation, the Tribunal emphasised once again that Hungary had never made binding representations or assurances in connection with the permanent evisceration of regulated prices. ${ }^{29}$ In addition, obliging Hungary to provide Electrabel with preferential rates for an indefinite time period would infringe upon the EU regulations on public aid. ${ }^{30}$

On the other hand, the Tribunal observed that the termination of the long-term agreement by the respondent (at the end of 2008) could potentially constitute a basis for bringing claims related to fair and equitable treatment. This is because terminating the agreement prior to the specified expiration date (originally 2010 and 2015 after prolongation) created the so-called stranded costs ${ }^{31}$ and the non-compensated loss would cause damage to the investor. ${ }^{32}$ Nevertheless, it should be noted that for the want of sufficient data at that stage of the proceedings, the Tribunal declared itself not competent for ruling on the matter.

Both cases discussed above show that the state enjoys a considerable autonomy in the scope of market liberalisation. As long as no individual promises or assurances are made to the investor, the state may reintroduce the administrative regulation of electric energy prices, e.g. for its own protection. However, it needs to be emphasised that this freedom has its limits, as exemplified by the case Total S.A. v. Argentina discussed below.

\subsection{Change in the market model and unreasonably low tariffs: the cases: National Grid Transco v. Argentina and Total S.A. v. Argentina}

Another group of cases concerns Argentina. Due to an economic crisis, the state was forced to introduce far-reaching reforms which altered the investment environment to a substantial degree. As a result, Argentina became the respondent in many proceedings heard by arbitration tribunals.

The findings of fact in the first case concerned an action brought by a British company named National Grid Transco plc which alleged a breach in the bilateral agreement on investment promotion and protection entered into by Great Britain and Argentina in 1993. ${ }^{33}$ Through its subsidiary named National Grid Finance B.V., the company and two American entities formed a consortium which participated in the privatisation ${ }^{34}$ (partial, as it concerned $65 \%$ of the shares) of a public company named Transener (Compañía de Transporte de Energía Eléctrica en Alta Tensión S.A.) engaged in the transmission of electric energy

\footnotetext{
29 Electrabel, Part IX, p. 3, point 9.10.

30 See: Judgement of TSUE in the case Dunamenti v. Commission, T-179/09, unpublished.

31 Stranded costs include the investment cost incurred only in the past, not yet recovered by the investors by the sale of electric energy and other services, and impossible to recover in a liberalised market.

32 Electrabel, Part VI, pp. 31-37, points 6.96, 6.109, 6.114.

33 National Grid P.L.C. v. Argentina (3 November 2008), UNCITRAL.

34 By using the previously incorporated state company named Citelec (Compañía Inversora en Transmisión Eléctrica Citelec S.A.).
} 
in the territory of Argentina. The transaction was completed in July 1993. In later years (1997, 1999, 2001), Transener was awarded government contracts for the construction, management and maintenance of a high-voltage grid. The services were rewarded with special remuneration (cánones) calculated in US dollars and regularly adjusted. ${ }^{35}$ However, in the wake of reforms introduced to solve the economic crisis, the provisions allowing for the calculation were repealed, and all tariffs for electric energy transmission could only be expressed in the Argentine peso. Simultaneously, the exchange rate was fixed at one peso to one dollar.

As a result, the claimant accused Argentina of violating the standard of fair and equitable treatment by, among others, an infringement upon the principle of legitimate expectations. ${ }^{36}$ The allegation was based on the view that dollar-based remuneration constituted an essential condition for making the investment decision. ${ }^{37}$ The company indicated that only that system gave it access to foreign capital market, necessary to finance the costs of operation, upgrade, expansion and maintenance of the electric energy infrastructure. Furthermore, the change in currency made the claimant incapable of covering operating costs and acquiring a reasonable return rate on the invested capital, guaranteed in the contract. ${ }^{38}$

In reaction to those claims, the respondent indicated that reasonable and legitimate expectations should be considered in the light of the relevant context. In this case, the law reform which resulted in altering the tariff calculation regime was introduced in the wake of a deep economic crisis and the measures were taken in an attempt to mitigate its consequences.

In reference to those arguments, the Tribunal observed at the outset that in every case, reasonable and legitimate expectations must be considered in the light of the circumstances of the individual case. The Tribunal then proceeded to indicate that the standard protects reasonable expectations of the investor at the moment of making the investment decision and in accordance with the terms offered by the host state (the basis for the decision). As discussed above, the expectations cannot fall beyond the ordinary level of business or regulatory risk. The Tribunal remarked that the investment was made at the time when, in the wake of the economic crisis, Argentina was trying to restore the image of a state open to foreign investments. ${ }^{39}$ The treaty with Great Britain was a crucial element of that effort, much like the strategy promoting investments in the state and, in the case in question, the prospectus of the privatised company, prepared and disseminated with the assistance of the Argentinian authorities. The document contained a crucial piece of information for the investor - the data on the investment conditions, which constituted the basis for assessing whether or not the principle of reasonable and legitimate expectations was violated (although in the end, the Tribunal never indicated that the actions of the state directly infringed upon said principle). In conclusion, the Tribunal ruled that Argentina did violate the provisions on fair and equitable treatment since:

- It fundamentally altered the legal framework in which the investor had operated,

\footnotetext{
35 In consideration of the US Consumer Price Index and the US Producer Price Index.

36 National Grid..., point 156.

37 Ibidem, point 63.

38 Ibidem, point 62 .

39 Ibidem, point 176.
} 
- It made no attempt to negotiate the conditions of operation in the two years that passed between the adoption of the contested measures and the sale of the shares by the claimant,

- It required the claimant to renounce the legal remedies it may have had as a condition to renegotiate the conditions of operation. ${ }^{40}$

Importantly, the Tribunal did not deny the state its right to take appropriate measures aimed at neutralising the negative effects of the economic crisis. As the Tribunal accurately observed: "what would be unfair and inequitable in normal circumstances may not be so in a situation of an economic and social crisis". The investor cannot be, in a manner of speaking, insulated from the socio-economic situation in the state. Therefore, the Tribunal decided that the standard of fair and equitable treatment was violated. However, the breach did not occur in January 2002, at the moment of adopting the law which altered the rules of calculating tariffs for electric energy transmission, but in June 2002, when the respondent required the claimant to renounce the legal remedies it may have had as a condition to renegotiate the conditions of operation. ${ }^{41}$

The other case, Total S.A. v. Argentina, concerned the regulation of electric energy prices. It is an unusual example because, in contrast to the two previously discussed cases related to administrative pricing (AES and Electrabel v. Hungary), Total S.A. made the investment at the moment of complete market liberalisation. Thus, electric energy prices were set by the market in line with the generation costs. ${ }^{42}$ Yet, in the wake of the economic crisis, the amendments to the Electricity Law and Decree 1.398/92 restricted the electric energy prices by establishing fixed price caps. Thus, the prices ceased to reflect economic costs of power generation. ${ }^{43}$

As a result, Total accused Argentina of violating the standards of fair and equitable treatment arising from Art. 3 of the bilateral agreement between France and Argentina on reciprocal encouragement and protection of investments of 3 July 1991. Specifically, the claimant invoked the principle of fair and reasonable expectations as a basis for its claims. Nevertheless, the respondent argued that an investor making an investment should consider possible changes in the investing conditions. Besides, the Electricity Law set forth no guarantees regarding the unchanging character of legal norms. The Tribunal separated those arguments by indicating that the free market (a given legal regime) as such cannot be the object of any promise made by the state in the framework of investment law. ${ }^{44}$ Further, the structure of a given legal system does not guarantee absolute permanence of the arising solutions; neither does it negate the right of the state to take appropriate measures in a crisis situation. ${ }^{45}$ In the light of the above, the Tribunal declared that the changes introduced by the respondent in the remuneration regime applicable to power generation companies did not constitute a breach of the principle of reasonable and fair expectations.

However, in the same case, the Tribunal determined that Argentina was in breach of the regulations on fair and equitable treatment as it violated the principle of economic

\footnotetext{
40 Ibidem, point 179.

41 Ibidem, point 180 .

42 Ibidem, p. 113, point 248.

43 Ibidem, p. 132, point 291.

44 Ibidem, p.143, point 310.

45 Ibidem, p.144, point 312; A similar determination was made by the Arbitral Tribunal in the case El Paso Energy International Company v. Argentina (31 October 2011), ICSID, Arb/03/15, point 274.
} 
equilibrium derived thereof. According to the said principle, the prices of electric energy should reflect the economic cost of the system. ${ }^{46}$ Thus, the Tribunal indicated that after the introduction of the regulation in question in 2002, tariffs for electric energy were unreasonably low. ${ }^{47}$ As a result, the return rate on the invested capital decreased drastically, barely allowing the investor to cover its variable costs. The Argentinian authorities were fully aware that such methods were at odds with the principles of economy and could not be regarded as fair and equitable in the understanding of Art. 3 BIT. ${ }^{48}$ Furthermore, the situation had its ramifications for energy security. Low prices encouraged consumers to use more electric energy which did not cause a spike in investments in new power generation resources due to the low level of tariffs. Consequently, the Tribunal indicated that reduction in investments could force Argentina to import electric energy (which would be a threat to its energy security) while, thus far, the state had been energy self-sufficient. ${ }^{49}$

The cases discussed above reveal a certain difficulty in the direct application of the principle of reasonable and legitimate expectations. In fact, the tribunals emphasised that a drastic change in the investment environment, including the legal, regulatory and business framework, violated the standard of fair and equitable treatment. However, the focus was placed not on the reasonable and legitimate expectations but rather on the incompatibility of the state's actions with its obligation to secure a stable legal framework for the investors' operations (National Grid Transco v. Argentina) ${ }^{50}$ and on the need for ensuring economic equilibrium of the administrative pricing regime by the host state (Total S.A. $v$. Argentina). ${ }^{51}$ Such a resolution confirms the restrictive attitude of the tribunals towards the principle in question as an investment protection method. On the other hand, the cases show that the tribunals make an attempt to protect the investors using the standard of fair and equitable treatment, although based on different principles.

\subsection{PSEG Global Inc. and Konya Ilgin Elektrik Üretimve Ticaret Limited Şikreti v. Turkey $^{52}$ : a stable legal framework for the investment}

The interpenetration between the principle of reasonable and legitimate expectations and the need for ensuring a stable legal framework is aptly illustrated by the case PSEG v. Tur$k e y$. The findings of fact concerned an American company named PSEG Global Inc. which invested in Turkey through its subsidiary named Konya Ilgin Elektrik Üretimve Ticaret Limited Şikreti. The investment involved the construction of a $425 \mathrm{MW}$ power plant in the

\footnotetext{
46 Ibidem, p. 150 , point 327.

47 Ibidem, p. 150, point 328.

48 Ibidem, p. 150, point 330.

49 Ibidem, p. 150, point 328.

50 However, it may be observed at this point that the conclusion regarding the violation of a stable legal framework was derived by way of invoking the principle of reasonable and legitimate expectations, see: points 171-178 of Total S.A. v. Argentina.

51 Note that in both cases the investors could not achieve a reasonable return rate on the invested capital because of the changes. However, only in the National Gird case was the resolution generally in keeping with the reasonable and legitimate expectations-i.e. a fundamental change to the legal framework for the operation. On the one hand, this situation reveals the need for considering the facts individually in every case. On the other hand, it points to a certain inconsistency in applying the principle of reasonable and legitimate expectations.

52 PSEG Global Inc. and Konya Ilgin Elektrik Üretimve Ticaret Limited Şikreti v. Turkey (19 January 2007), Arb/02/5 ICSID.
} 
Konya Province (officially approved by the Ministry of Energy in 1995), a project inspired by Act No. 3096 from 1984 which allowed private investor to generate electric energy on special terms. Essentially, the Act was intended to encourage foreign investors to operate in the Turkish market. (Additionally, the investment in question concerned the mining sector as well.) Under the adopted BOT model (build-operate-transfer), foreign investors were obliged to sell (under a long-term contract) the generated electric energy to an energy company indicated by the state (TEAS). Upon the expiry of the state-approved duration of the investment (in this case: 38 years) the ownership of the power plant was to be transferred to the state. In exchange for accepting the terms, the price of electric energy was established on the basis of preferential tariffs, calculated in accordance with the terms accepted in the long-term agreement between the investor and the state-owned TEAS company. Additionally, the tariffs were guaranteed by the Treasury. Finally, the Ministry of Energy approved the investment project prepared by PSEG in November 1995. However, as the Turkish Constitutional Tribunal challenged the BOT model (arguing that it should be governed by the provisions of public law, i.e. concession, and not private law), the long-term agreement was never signed, although the terms of the investment were accepted by the Turkish Council of State in the Concession Contract. Several weeks before the contract came into force, Turkey summoned the claimants to revise the tariff structure by adding several new factors related to coal extraction, increased capacity of the power plant, etc. Those circumstances substantially increased the investment cost. The negotiations conducted in the following years failed to produce satisfying results. In addition, since in 2001 the Turkish parliament repealed the laws on guarantees for energy sector investments granted by the Treasury (Act No. 4628 on the electric energy market), the project became too risky in the eyes of the investor (while the claimants argued that the amendment practically caused the expiry of the concession).

As a result, the claimants argued that the respondent was in breach of the provisions on fair and equitable treatment, including the principle of reasonable and legitimate expectations and the requirement to secure a stable legal framework, set forth in Art. 2.3 of the bilateral agreement on investment encouragement and protection of 3 December 1985 signed by Turkey and the USA. In response to the allegation, Turkey indicated primarily the lack of any official legal basis - a decision regarding the concession or an agreement which would grant any rights (including guarantees) to the claimants. ${ }^{53}$

With reference to those arguments, the Tribunal reminded the parties that a breach of the principle of reasonable and legitimate expectations occurs if the actions of the state are inconsistent, lead to arbitrary modification of the legal framework or involve endless normative changes to the detriment of the investor. ${ }^{54}$

The Tribunal declared that not all allegations made by the claimants fell within the scope of the principle in question, mostly since there was no binding evidence for the existence of guarantees made by the state, either in the form of a concession (under public law) or a long-term agreement (under private law). ${ }^{55}$ It was also doubtful whether or not Turkey had encouraged the claimant individually to make the investment. Although the BOT model was aimed to promote foreign investment, it was an element of general state policy unrelated to any promise made to a specific investor. ${ }^{56}$

\footnotetext{
53 PSEG, p. 61, points 233-235.

54 Ibidem, p. 63, point 240.

55 Ibidem, p. 63, point 242.

56 Ibidem, p. 63, point 243.
} 
Consequently, the Tribunal established that Turkey did not explicitly violate the principle of reasonable and legitimate expectations but failed to meet the requirement of securing a stable and predictable legal framework for the operator's business. ${ }^{57}$ In justifying its position, the Tribunal observed that the situation resembled a "roller-coaster" of continuing legislative changes, especially in regard to the requirements relating, in law or practice, to the continuous change in the conditions governing the corporate status of the investment, the lack of an unequivocal assessment of the relevance of public and/or private law regulations and the changes in tax legislation. ${ }^{58}$

Thus, although no investor can expect the investment conditions to remain absolutely unchanged in future, it may legitimately be assumed that the host state will act in a fair and equitable manner. Since the objective assessment of the investment environment (in terms of both law and business) at the moment of the investment indicated fair and equitable treatment, it was fair to expect the state to uphold its standards of conduct. ${ }^{59}$

Thereby, the Tribunal confirmed the state's obligation to refrain from introducing any drastic changes to the legal environment as at the moment of the investment (Jeżewski 2014). Although the investor must consider the risk of the investment, the declaration that a series of legal acts is unconstitutional (despite the presumption of their compliance with the applicable law) which fundamentally changes the investment terms seems to go beyond the realm of predictability.

\subsection{Limiting support for renewable energy sources: the case Charanne B.V. and Construction Investment S.A.R.L. v. Spain}

It is interesting to consider in detail the system of promoting renewable energy sources in Spain. ${ }^{60}$ The case is important in that, with the increasing number of programmes supporting renewable energy sources, it sheds some light on doubts whether a state providing investors with certain profits has full autonomy to determine their amount.

The findings of fact in the dispute between Charanne B.V. (Denmark), Construction Investment S.A.R.L (Luxembourg) and the Kingdom of Spain concerned the reduction in subsidies offered the photovoltaic solar power plants by the state. Royal Decrees 661/2007 and 1578/2008 established a special support regime which secured above-average premiums in the solar power plant sector. In 2008, when the level of subsidies reached its peak, they were set at 389 euros/MWh, while the market price for electric energy equalled 45 euros/MWh. The situation led to a dynamic growth of the energy sector based on solar technology, as confirmed by the fact that the goals established in Royal Decree 661/2007 for the year 2010 were attained by 2008 .

However, in the wake of the economic crisis, the mechanism became an intolerable burden for the state budget and was consequently curbed under relevant legal regulations. Firstly, the state introduced new time limits for maintaining the guaranteed tariffs, shortening the original time frames from 40 to 25 years. Secondly, the tariffs were reduced, and the number of hours covered by the support regime for photovoltaic facilities was cut by 30\%: from 1725 to 1250 per year (Royal Decree 14/2010). Those measures enhanced the

\footnotetext{
57 Ibidem, p. 63, point 253.

58 Ibidem, p. 63, point 250.

59 Ibidem, p. 63, point 255.

60 Charanne B.V. and Construction Investment S.A.R.L. v. Spain (21 January 2016), Arb/062/2012 SCC.
} 
financial stability of the state. However, as they also disrupted the stability of the legal situation of investors, some doubts were raised with regard to their lawfulness (Soria 2011).

In the light of the above, the claimants alleged a violation of Art. 10.1 of the Energy Charter Treaty which established the requirement of fair and equitable treatment of foreign investors, deriving thereof the principle of reasonable and legitimate expectations. During the proceedings, the Tribunal reminded the parties that a determination or whether or not the said principle had been violated required objective standards due to the insufficiency of the investors' subjective belief that some rights had been granted for an indefinite period. ${ }^{61}$ The claimants argued that the respondent had led a broad-based campaign encouraging investment in the solar energy sector. In the eyes of the Tribunal, such a campaign was insufficient to create reasonable expectations that the tariffs for electric energy generated at photovoltaic facilities would remain unchanged. Admitting the existence of such expectations would imply that the legal framework of the host state could not change regardless of the circumstances. Practically, it would be tantamount to the acceptance of a stabilisation clause by Spain (Kosiński 2011) while said clause was not included in any agreement. As a result, any modification of the tariff or any reduction of the number of hours eligible for the support would be at odds with international investment law (Kosiński 2011). ${ }^{62}$

According to the Tribunal, in order to make a reasonable investment decision, the claimants should have performed an analysis of the regulatory environment. Such an analysis would have revealed that the introduction of changes to the subventions in later years was highly probable. Furthermore, the authority emphasised that in order to be in violation of the principle of legitimate expectations, the state had to act unreasonably, disproportionately or contrary to the public interest. ${ }^{63}$ In the light of those premises, the Tribunal observed that despite the revisions in the support system introduced since 2010, its essence remained unchanged. Furthermore, the revisions were not capricious but resulted from the excessive investments in the sector and the economic crisis which plagued Spain. Finally, the Tribunal remarked that the system was applicable both to foreign and to national investors which prevented any arbitrariness in the support granted.

Although the decision to dismiss the case may seem controversial in the eyes of the investors, their expectations could hardly be called reasonable and legitimate. As argued above, the analysed principle does not guarantee that the regulatory regime will remain unchanged or that any privileges are granted in perpetuity; it is concerned only with the expectations that the conduct of the state will not be drastically at odds with its assurances which affected the investment decision. Thus, the investor's assumption that the amount of the subventions would surpass manifold the market price of electric energy for the entire term of the investment falls beyond the scope of the invoked principle. A determination to the contrary would lead to a conclusion that the investor does not consider the risk-in this case, of a regulatory nature-carried by the investment, even though such a consideration lies at the foundation of the very concept of investing.

${ }^{61}$ Charanne B.V. and Construction Investment S.A.R.L, p. 113, point 495.

${ }^{62}$ Ibidem, p. 115, point 503.

${ }^{63}$ Ibidem, p. 117, point 514. 


\section{Conclusions and policy implications}

The analysis reveals that standards and principles of international investment law may be effective in limiting investment risk in the energy sector. However, the discussed cases demonstrate that a claim based on the principle of reasonable and legitimate expectations may be misguided in many cases. This is chiefly because of a series conditions that need to be satisfied in order to prove a violation of said principle. The difficulty of the analysis presented by the authors is also related to the fact that a relatively long time of the investment process in the energy sector has to be taken into account. In such a long period, a subjective belief of an investor that rights have been granted may be repeatedly compromised. The investors' fair expectations may change because they depend on a range of factors, including the nature of the violation and the circumstances of the case. But, like it was underlined in the case $L G \& E v$. Argentina, the Arbitral Tribunal they are mostly based on the conditions offered by the host State at the time of the investment. The fair circumstances should not be established unilaterally by one of the parties and have to be enforceable by law. The legal basis, understood also as recognised general principles, in the event of infringement by the host State, gives the investor a possibility to compensate the damages raised, except for those caused in the event of a state of necessity.

Furthermore, it is erroneous to argue that rights, once granted, are valid for an indefinite period. The jurisdiction of arbitration tribunals reveals that the principle of reasonable and legitimate expectations does not guarantee the unchanging character of the law but only allows the investor to expect that the conduct of the host state will not change drastically after the investment decision has been made. It is crucial for the assurance made by the state to be legally binding, e.g. by the inclusion of a stabilisation clause. Otherwise, the expectations may be deemed to lack objectivity, which could lead the tribunal to the determination that the principle in question is not applicable. Meanwhile, note that the principles must stay within the realm of reasonableness. As emphasised in the case Total $v$. Argentina, maintaining a given legal regime cannot be the object of any promise made by the state in the framework of investment law. The state should reserve its right to take appropriate measures in the event of a justified threat to its public interest. However, in the same case, the Tribunal saw fit to invoke the principle of economic equilibrium. Thus, in the cases concerning price regulation or a support system, it should be considered whether applying that principle would not be more reasonable. However, in such a case, the claimant needs to demonstrate that the tariffs set by the host state are indeed unreasonably low and preclude the recovery of the invested capital. Only such circumstances may be considered a violation of said principle and thereby of the standard of fair and equitable treatment.

Finally, there is an inconsistency in applying the principle of reasonable and legitimate expectations and the requirement to secure a stable legal framework. Arbitration tribunals show a certain reticence with regard to the unequivocal assessment of the invoked principles. At the same time, it seems that altering tariffs (e.g. in the case of electric energy prices) as a regulatory method falls within the scope of a stable legal framework rather than reasonable and legitimate expectations. This is because this method is primarily an element of the general regulation policy of the state and not an individual promise. At this point, let us emphasise that it is precisely this method which often becomes the object of dispute (between the investor and the state) in the energy sector. Therefore, it could be somewhat surprising that investors, aware of the existence of regulatory risk (often determined by social factors), seem to downgrade 
this contingency in the decision-making process. The fact that investors focus only on the economic risk rather than on regulatory threats ${ }^{64}$ may offer a partial explanation of this quandary. In this context, the standpoint of the Arbitral Tribunal in the case Duke v. Ecuador seems particularly pertinent. ${ }^{65}$ The Tribunal pointed to the need for a holistic approach with regard to the expectations and rightly argued that their assessment should take into account the regulatory risk understood as well as through a prism of political, socio-economic, cultural and historical aspects. It seems that in most cases discussed above, it is precisely such an attitude that the investors lacked.

Acknowledgements The publication was written as a result of the author's (Michał Krzykowski) internship in European University Institute in Florence, co-financed by the European Union under the European Social Fund (Operational Program Knowledge Education Development), carried out in the project Development Program at the University of Warmia and Mazury in Olsztyn (POWR.03.05. 00-00-Z310/17)

Open Access This article is licensed under a Creative Commons Attribution 4.0 International License, which permits use, sharing, adaptation, distribution and reproduction in any medium or format, as long as you give appropriate credit to the original author(s) and the source, provide a link to the Creative Commons licence, and indicate if changes were made. The images or other third party material in this article are included in the article's Creative Commons licence, unless indicated otherwise in a credit line to the material. If material is not included in the article's Creative Commons licence and your intended use is not permitted by statutory regulation or exceeds the permitted use, you will need to obtain permission directly from the copyright holder. To view a copy of this licence, visit http://creativecommons.org/licenses/by/4.0/.

\section{References}

Boute, A. (2012). Combating climate change through investment arbitration. Fordham International Law Journal, 35 (3), 613-614.

Brown, C. (2008). The protection of legitimate expectations as a 'general principle of law': Some preliminary thoughts. TDM, 1, . https://www.transnational-dispute-management.com/artic le.asp?key=1303. Accessed 11 Aug 2018.

Burton, S. J., \& Andersen, E. G. (1995). Contractual good faith: formation, performance, breach, enforcement. New York: Little, Brown \& Co.

Camby, J.-P. (2006). Sécurité juridique et insécurité jurisprudentielle. $R D P, 6,1505$.

Feinman, J. M. (2014). Good faith and reasonable expectations. Arkansas Law Review, 67, 525.

Henderson, R. (1990). The doctrine of reasonable expectations in insurance law after two decades. Ohio State Law Journal, 51(4), 823-824.

Jeżewski, M. (2011). Międzynarodowe prawo inwestycyjne, Warszawa.

Jeżewski, M. (2014). Swoboda orzekania sądów międzynarodowych co do prawa krajowego ze szczególnym uwzględnieniem arbitrażu inwestycyjnego. In: Wyrozumska, A. (ed.) Swoboda orzekania sądów międzynarodowych, Łódź.

Kosiński, P. (2011). Rola prawa krajowego w międzynarodowych sporach inwestycyjnych. Studia Iuridica Toruniensia, 8, 95.

Merzouk E. B. (2003). La fausse consécration du principe de sécurité juridique, Paris.

Michel, V. (2009). Brèves observations sur l'application des principes de sécurité juridique et de confiance légitime. Gazette du Palais, , 43, 43.

Potestà, M. (2013). Legitimate expectations in investment treaty law: Understanding the roots and the limits of a controversial concept. ICSID Review, 18, 7-8.

Przybojewska, I. (2017). Znaczenie transeuropejskich sieci energetycznych dla zapewnienia bezpieczeństwa energetycznego, Warszawa.

\footnotetext{
64 The economic risk is an amount of money related to the cost of the investment which the investor is taking into account during the investment. One of the economic risks may be decrease in the profitability of the investment resulting for example from changing legal environment (regulatory threat).

65 Duke Energy Electroquil Partners \& Electroquil S.A. v. Republic of Ecuador (18 October 2008), Arb/04/19 ICSID, point 340.
} 
Rahdert, M. C. (1986). Reasonable expectations reconsidered. Connecticut Law Review, 18, 323.

Rahdert, M. C. (1998). Reasonable expectations revisited. Connecticut Insurance Law Journal, 5, 107.

Reinisch, A. (2008). Standards of investment protection. Oxford.

Reinisch, A., Knahr, C. (Eds.). (2008). International investment law in context. Eleven International Publishing, The Hague.

Schreuer, C. (2005). Fair and equitable treatment in arbitral practice. The Journal of World Investment \& Trade, 6, 357.

Schreuer, C., \& Kriebaum, U. (2010). At what time must legitimate expectations exist? In J. Werner \& A. H. Ali (Eds.), A liber amicorum: Thomas Wälde law beyond conventional thought. London: CMP Publishing Ltd.

Soria, J. (2011). Spain: new regulations on renewable energy facilities. International Law Review,4, s, $133-136$.

Tudor, I. (2008). The fair and equitable treatment standard in the international law of foreign investment. Oxford: Oxford University Press.

Turpin, D. (2003). Droit constitutionelle. Paris: PUF.

Varian, H. R. (1992). Microeconomic analysis (3rd ed.). New York: Norton.

Walter, A. (2008). The investor's expectations in international investment arbitration. In A. Reinisch \& C. Knahr (Eds.), International investment law in context. The Hague: Eleven International Publishing.

Yannaca-Small, K. (2008). Fair and equitable treatment standard: Recent developments. In A. Reinisch (Ed.), Standards of investment protection, Oxford.

Publisher's Note Springer Nature remains neutral with regard to jurisdictional claims in published maps and institutional affiliations.

\section{Affiliations}

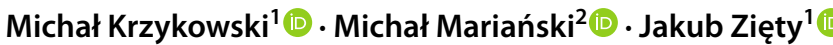

Michał Krzykowski

michal.krzykowski@uwm.edu.pl

http://www.uwm.edu.pl/en

Michał Mariański

michal.marianski@uwm.edu.pl

Jakub Zięty

jakub.ziety@uwm.edu.pl

1 Department of Economic and Commercial Law, Faculty of Law and Administration, Centre for Bioeconomy and Renewable Energies, University of Warmia and Mazury, Olsztyn, Poland

2 Department of Financial and Tax Law, Faculty of Law and Administration, University of Warmia and Mazury, Olsztyn, Poland 